\title{
THE EFFECT OF CORPORATE GOVERNANCE ON STOCK LIQUIDITY IN BANKING SUB-SECTOR COMPANIES: EVIDENCE FROM INDONESIAN STOCK EXCHANGE
}

\author{
Maharani G. ${ }^{*}$, Hartoyo I.S., Sasongko H. \\ School of business, Bogor Agricultural University, Indonesia \\ *E-mail: gmaharani.95@gmail.com
}

\begin{abstract}
The implementation of good corporate governance is crucial in the banking industry because bank has its function as intermediary, making them as a high level risk industry. Moreover, according to the data, the poor corporate governance is one of the main causes of the 19971998 Asian Financial Crisis, including Indonesia. This fact has made the quality of corporate governance as an important thing that investors consider when investing. Liquidity is an important factor for both investor and firm; if an investor owning an illiquid stock it will be harder for them to sell and if a firm has an illiquid stock it will make investing to them becomes less attractive. This study explores the effect of corporate governance on stock liquidity in Banks. The quality of corporate governance is scored using 21 indicators from OJK regulation, for liquidity Amihud illiquidity estimate and stock turnover are used as proxies. Variable of size, leverage, return volatility, and growth are used control variable. By using a sample of 26 banks from 2012 to 2016, we find that Indonesian Banks already has good corporate governance and our multiple regression analysis results showed that there is a significant relationship between corporate governance and stock liquidity, suggesting that better governed firms has greatly improved stock liquidity. Furthermore we find that the quality of board of commissioner greatly impact stock liquidity.
\end{abstract}

\section{KEY WORDS}

Corporate governance, stock liquidity, Indonesian banks.

The survey conducted by McKinsey \& Co (2002) shows that corporate governance is an important thing that investors consider when investing. The results of the survey shows that $61 \%$ of investors in Asia consider governance conditions as important as financial indicators, $21 \%$ of investors consider governance conditions to be more important than financial indicators, $18 \%$ consider financial indicators to be more important than governance conditions. $82 \%$ of investors consider the quality of governance to be important, especially in emerging market countries, because poor corporate governance is one of the main causes of the 1997-1998 Asian Financial Crisis, including Indonesia (Nam and Nam 2004).

Good corporate governance will increase financial and operational transparency of the company (Chung et al. 2010). Corporate transparency is an absolute thing for prospective investors. Merton (1987) suggests that, investors when investing in shares will consider only those companies whose information is clear and complete. Good corporate governance can increase stock liquidity due to an increase in investor interest (Ali et al. 2017).

According to Handa and Schwartz (1996) investors want three things from the market, namely liquidity, liquidity, and liquidity. A stock is said to be liquid if the stock can be sold on a large scale quickly at a low cost (Harris 2003). In addition to being important for investors, from the side of the issuing company, having liquid shares will reduce the cost of equity (Butler et al. 2005). Cheaper cost of equity occurs because companies do not need to provide more incentives to the shares they issue to attract investors. Besides reducing the cost of equity, according to Cheung et al. (2015), having liquid shares can increase company value because the company is considered to have good governance.

The Indonesian capital market groups companies into nine sectors. The financial sector is the sector that has the highest market capitalization of the other 8 sectors, namely $29.66 \%$ of the total capital market capitalization of Indonesia and has the second largest daily trading frequency, which is 48.11 times (Indonesia Capital Market Statistics 2017). The banking 
industry dominates the financial sector, which has a total capitalization of Rp. 1339854 million, or $90.64 \%$ of the total financial sector (IDX Statistics 2016). This shows that the banking industry is very attractive to investors.

The banking industry has a big role as one of the leading components in national development. The implementation of good governance is crucial in the banking industry. The Financial Services Authority (OJK) and Bank Indonesia (BI) as a bank regulator institution issued various rules that made the banking industry as a regulated industry. The tight supervision of the banking industry can not be separated from the role of banks as intermediary institutions, namely collecting public funds in the form of deposits and channeling to the public in the form of credit, resulting in a high risk complexity of the banking industry. Although the banking industry has a high level of risk, this industry remains attractive to investors, research on how the effect of corporate governance on stock liquidity in the banking sub-sector companies in Indonesia is interesting to do.

\section{LITERATURE REVIEW}

Research on the effect of corporate governance on stock liquidity has been carried out several times. In the past, several studies examine the relation between external corporate governance and liquidity such as Bacidore and Sofianos (2002) and Brockman and Chung (2003). By contrast, several studies argue that internal corporate governance is related to liquidity as well. Research about the effect of internal corporate governance on stock liquidity has been carried out in several countries such as America (Chung et al. 2010), Thailand (Prommin et al. 2014), Malaysia (Foo and Zain 2010), France (Ajina et al. 2015), and Australia (Ali et al. 2017), but similar studies have not been conducted in Indonesia. The studies carried out in these countries cannot be generalized because of differences in characteristics in each country, namely in terms of indicators of quality assessment of corporate governance and the stock trading system. For example Chung et al. (2010) measure governance quality by using the governance factors reported by the Institutional Shareholder Services (ISS), which only available for U.S firms, Prommin et al. (2014) measure governance quality by using the governance standards from the Securities and Exchange Commission (SEC) of Thailand, and Ali et al. (2017) construct a CG index by following the Horwath report.

In regards to the stock trading system, each country has different trading system. For example stock market in U.S has quote-driven trading system where the designated market makers quote the bid-ask prices and supply liquidity to the market. On the contrary, Australia has a pure order-driven trading system where public limit orders establish bid-ask prices and provide liquidity to market participants. Similar with Australia, Indonesia also has order-driven trading system which implies that stock liquidity is being fully provide by market participants.

The liquidity is fully decided by the stocks holder, so the decision of sell and buy prices are in their hands. These stocks holder decides the amount of sell and buy prices from their paradigm on the company itself. If they think the company is reliable then they will buy the stocks, if they think the otherwise then they will avoid to buy any stocks from the company. This makes having a good corporate governance is an important matter for a company, because how high their stocks will sell is depends on how good the corporate governance of a company is.

The previous stock markets research by Chung et al. (2010), Prommin et al. (2014), and Ali et al. (2017) were done in every sector except financial. Financial sector can not be researched together with other sectors because the indicator for corporate governance in financial sector is made specific by the regulations. This makes a research concerning corporate governance in financial sector needs to be done separately. The regulations in other sectors are not as strict as in financial sector, this makes it easier to tell which companies has good corporate governance. In financial sector, the strict regulations and the tight supervisions make companies racing to apply good corporate governance; these companies almost have equally good corporate governance. This is where the problems 
becomes interesting, amid these same level of good corporate governance, does a litte difference in the level of corporate governance going to affect the liquidity of the stocks?

Hypothesis development. In the management of the company there is a separation between shareholders as the owner of the stocks and manager of the company. Agency relationship according to Jensen and Meckling (1976) is a contract between the principle and the manager of the company where the company owner (principle) entrusts the management of the company to the manager in accordance with the principle of the principle by delegating some decision-making authority to the manager (agent). Agency relationships like this sometimes conflicts arised when the interests of the manager (agent) are more dominant than the interests of the principle.

Information asymmetry is one example of a conflict of interest. Information asymmetry is a condition when one party has information that the other party does not have (Kuper 2005). For example, when a manager hides an information from the owner, it will create a moral hazard, for example transferring the wealth of the company to itself (Switzer and Wang 2013). To cover up fraud, opportunistic managers will present information that is beneficial to themselves by way of sorting information that will be conveyed to shareholders.

Corporate transparency is a major and important factor for potential investors. Merton (1987) suggests that investors when investing in shares will consider only those companies whose information is clear and complete. Effective corporate governance can improve financial and operational transparency of the company (Chung et al. 2010).

Diamond (1985) shows that increased information disclosures reduce information asymmetry between management and traders and diminishes traders' motivation to acquire private information, resulting in less heterogeneity among trader beliefs and smaller speculative positions among informed traders. Facing less adverse selection problems, traders provide more liquidity for stocks of well-governed firms (Glosten \& Milgrom, 1985). Theory therefore suggests that poor corporate governance may impair stock market liquidity to the extent that poor governance is associated with low financial and operational transparency.

\section{METHODS OF RESEARCH}

Our data consist of 26 banks (Table 1) listed on the Indonesia Stock Exhange (IDX) from period 2012-2016. The criteria we used to pick the sample are: the firms already listed before 2012, not delisted in period 2012-2016, and the availability of the governance data, financial data, and liquidity data. The governance data are obtained from governance reports in annual reports. The data for the calculation of stock liquidity, such as stock prices and trading volume, is obtained from IDX website, and the financial information obtained from firms annual reports, which are available in each firms website. The final sample is a panel data set containing a total of 130 observations (26 banks over 5 years).

Table 1 - List of banks

\begin{tabular}{llllll}
\hline No & Stocks & Bank & No & Stocks & Bank \\
\hline 1. & AGRO & BRI Agro Niaga & 14. & BNGA & Bank CIMB Niaga \\
2. & BACA & Bank Capital Indonesia & 15. & BNII & Bank Maybank Indonesia \\
3. & BBCA & Bank Central Asia & 16. & BNLI & Bank Permata \\
4. & BBKP & Bank Bukopin & 17. & BSIM & Bank Sinarmas \\
5. & BBNI & Bank Negara Indonesia & 18. & BSWD & Bank of India Indonesia \\
6. & BBRI & Bank Rakyat Indonesia & 19. & BTPN & Bank Tabungan Pensiunan Nasional \\
7. & BBTN & Bank Tabungan Negara & 20. & BVIC & Bank Victoria International \\
8. & BDMN & Bank Danamon Indonesia & 21. & INPC & Bank Artha Graha International \\
9. & BEKS & BPD Banten & 22. & MCOR & China Construction Bank \\
10. & BJBR & Bank Jabar Banten & 23. & MEGA & Bank Mega \\
11. & BKSW & Bank QNB Indonesia & 24. & NISP & Bank OCBC NISP \\
12. & BMRI & Bank Mandiri & 25. & PNBN & Bank Pan Indonesia \\
13. & BNBA & Bank Bumi Arta & 26. & SDRA & Bank Woori Saudara \\
\hline
\end{tabular}


Measures of corporate governance quality. This study uses 21 (Table 2) indicators to assess the quality of corporate governance. The indicators used in this study are the results of considerations from various literatures such as the rules of corporate governance guidelines issued by OJK, namely the Financial Services Authority Regulation Number 21 / POJK.04 / 2015 concerning the implementation of guidelines for open corporate governance in Indonesia; Financial Services Authority Regulation Number 32 / POJK.04 / 2015 concerning plans and implementation of general meeting of shareholders; Financial Services Authority Regulation Number 33 / POJK.04 / 2015 concerning directors and commissioners of issuers or public companies; Financial Services Authority Regulation Number 34 / POJK.04 / 2015 concerning nomination and remuneration committees of issuers or public companies; and Financial Services Authority Regulation Number 55 / POJK.04 / 2015 concerning the establishment and guidelines for the implementation of the audit committee's work, recommendations on the implementation of corporate governance listed in the Financial Services Authority Circular Letter Number 32 / POJK.04 / 2015, and similar research journals. The calculation of governance quality is done by giving a value that is worth 1 if the indicator is applied, and is worth zero if the indicator does not reach the target, so the range of governance quality values will be obtained from zero to 21 . This method of granting is similar to Sawicki's (2009) and Prommin et al. (2014).

Table 2 - Corporate governance indicator

\begin{tabular}{|c|c|c|}
\hline Category & & Corporate governance standard \\
\hline \multirow{16}{*}{$\begin{array}{l}\text { Board of } \\
\text { Commisioner }\end{array}$} & \multirow{3}{*}{ Common } & $50 \%$ of commissioners are independent commissioners \\
\hline & & Commissioner meetings at least 1 time every 2 months \\
\hline & & Commissioners and directors' meetings are at least 1 time every 4 months \\
\hline & \multirow{7}{*}{ Audit } & There is an audit committee \\
\hline & & The audit committee has a minimum of 3 members \\
\hline & & The composition of independent commissioners and independent parties \\
\hline & & \\
\hline & & Audit committee background \\
\hline & & Audit committee meetings at least 1 time every 3 months \\
\hline & & Report of the audit committee in the annual report \\
\hline & \multirow{4}{*}{ Risk } & There is an risk committee \\
\hline & & The risk monitoring committee has a minimum of 3 members \\
\hline & & $\begin{array}{l}\text { The composition of independent commissioners and independent parties } \\
\text { is at least } 51 \%\end{array}$ \\
\hline & & Risk monitoring committee background \\
\hline & Nomination & There is a nomination committee \\
\hline & Remuneration & There is a remuneration committee \\
\hline \multirow{4}{*}{ Board of Director } & Common & $\begin{array}{l}\text { Establishment of an internal audit work unit, risk management work unit, } \\
\text { compliance work unit } \\
\text { Self assestment board of director }\end{array}$ \\
\hline & \multirow{3}{*}{$\begin{array}{l}\text { Annual } \\
\text { Report }\end{array}$} & Annual reports are published no later than the end of the fourth month \\
\hline & & after the financial year ends \\
\hline & & Completeness of the contents of the annual report \\
\hline \multicolumn{2}{|l|}{ GMS } & GMS is held at least once a year \\
\hline
\end{tabular}

Liquidity measures. The dependent variable of our study is stock liquidity. We measure stock market liquidity in Indonesia banking sector using two alternative methods: the Amihud illiquidity estimates (ILLIQ) and stock turnover (STO). Amihud's (2002) illiquidity estimates or ILLIQ is measured as the daily ratio of absolute stock return to trading volume in Indonesian rupiah, averaged over a number of trading days in the financial year, that is, how much the absolute stock price changes with one rupiah trading volume. ILLIQ is a proxy of stock liquidity dimension's, depth or price impact of trade, which refers to the ability of market to absorb a large quantity of trade without having a large price impact.

$$
\operatorname{ILLIQ}_{\mathrm{it}}=\frac{1}{\mathrm{D}_{\mathrm{it}}} \sum_{\mathrm{d}=1}^{\mathrm{D}_{\mathrm{it}}} \frac{\left|\mathrm{R}_{\mathrm{idt}}\right|}{\operatorname{VOLD}_{\mathrm{idt}}},
$$


Where: $\left|R_{\text {idt }}\right|$ is the absolute stock return of bank $i$ on day $d$ of year $t, V O L D_{\text {idt }}$ is the trading volume of bank $i$ on day $d$ of year $t$, and $D_{i t}$ is the number of days with available data for bank $i$ in year $t$. The higher the ILLIQ, the lower the stock liquidity will be.

Stock turnover (STO) captures trading frequency: how many times a share changes owners. STO is a proxy of stock liquidity dimension's, immediacy, which represents the trading speed, that is, the speed with which buy or sell orders can be executed:

$$
\mathrm{STO}_{\mathrm{it}}=\frac{\mathrm{VOL}_{\mathrm{it}}}{\mathrm{N}_{\mathrm{it}}}
$$

Where: $V O L_{i t}$ is the total number of shares traded for bank $i$ in a year $t$, and $\mathrm{N}_{\mathrm{it}}$ is the number of outstanding shares for firm $i$ in an year $t$. Both volume data for each bank and outstanding shares data is collected on a yearly basis. The higher STO, the higher the stock liquidity will be.

Control variable. Four firm characteristics as control variables is included to isolate the effect of CGQ on stock liquidity: firm size, leverage, return volatility, and growth opportunities (Prommin et al., 2014; Ali et al., 2017). Firm size is used as the control variables because larger firms have more information available; they may attract much more research on their stocks and thus have less adverse selection risk (Diamond and Verrecchia, 1991). The proxy for firm size is the natural logarithm of market capitalization (In (MC)), which is calculated as the number of shares outstanding times share price at the end of a financial year. Leverage (lev) variable which is calculated by the book value of the total liabilities over the book value of total assets, also is used as control variable. Return volatility (Rvol) increases the uncertainty of the cost of the holding stock, and thus more volatile stocks have a wider bidask spread and more information asymmetry (Ho and Stoll, 1981). Return volatility is used as the standard deviation of daily stock returns. Moreover, high growth firms may have more information asymmetry problem that leads to lower stock liquidity. We measure growth opportunities by the market to book value (growth).

To test the effect of corporate governance on stock liquidity the formulation used is the following regression equation:

$$
\text { Liquidity }_{i, t}\left(\text { ILLIQ }_{i, t}, \text { or STO }_{i, t}\right)=\alpha_{0}+\beta_{1} \text { CGQ }_{i, t}+\beta_{2} \text { Size }_{i, t}+\beta_{3} \operatorname{Lev}_{I, t}+\beta_{4} \text { Rvol }_{i, t}+\beta_{5} \text { Growth }_{i, t}+\varepsilon_{i, t} \text {, }
$$

Where: the subscripts denotes individual firms $(=1,2, \ldots, 26)$, time period $(t=2012$, $2012, \ldots, 2016), \alpha$ and $\beta$ are parameters to be estimated, and $\varepsilon$ is the error term.

The firm fixed effect (FE) method is employed to control for unobserved heterogeneity, due to time-unvarying omitted variables that differ across firms but are constant over time. While estimating the effects of independent variables on dependent variables, the FE method focuses on over time changes in the variables. Since this method focuses particularly on the time-series variation between CGQ and stock liquidity, and a causal relation between them can be examined using their time-series covariation, FE provides an additional insight into the empirical linkage between CGQ and the two dimensions of stock liquidity.

\section{RESULTS OF STUDY}

Table 3 shows the development of the quality of corporate governance in the banking subsector. In general, the banking subsector in Indonesia has implemented good governance. This can be seen in the average value of the quality of corporate governance above $86 \%$ and continues to increase every year. The minimum value during the study period occurred in 2012, which are 14 reported by Bank Swadesi. In 2012 the annual report issued by Bank Swadesi was incomplete, i.e. it did not meet indicators 2, 3, 10, 4, 18, and 19. In 2012 there were 2 companies that obtained maximum scores, namely BRI and Bank Mandiri, in 2015 there were 2 companies, namely Bank BTN and Bank Permata, and in 2016 there were 3 companies namely Bank BRI, Bank QNB Indonesia, and Bank Permata. 
Table 3 - The quality of the banking sub-sector corporate governance in 2012-2016

\begin{tabular}{llllll}
\hline \multirow{2}{*}{ Statistic } & \multicolumn{5}{l}{ Corporate governance quality } \\
\cline { 2 - 6 } & 2012 & 2013 & 2014 & 2015 & 2016 \\
\hline Maximum & 21 & 20 & 20 & 21 & 21 \\
Minimum & 14 & 15 & 17 & 16 & 15 \\
Mean & 18.08 & 18.11 & 18.50 & 18.69 & 18.81 \\
Mean (\%) & 86.08 & 86.26 & 88.09 & 89.01 & 89.56 \\
\hline
\end{tabular}

Table 4 - Regression results of the ILLIQ sub-sector banking panel data model

\begin{tabular}{lllll}
\hline Variable & Coefficient & Std. Error & t-Statistic & Prob. \\
\hline CGQ & -0.00001930 & 0.00000509 & -3.796639 & 0.0003 \\
Size & -0.00001720 & 0.00000973 & -1.769803 & 0.0798 \\
Lev & 0.00068500 & 0.00021000 & 3.257282 & 0.0015 \\
Growth & 0.00000117 & 0.00000747 & 0.157113 & 0.8755 \\
Rvol & 0.00132400 & 0.00061600 & 2.150736 & 0.0339 \\
Constant & 0.00036500 & 0.00038500 & 0.949277 & 0.3448 \\
\hline R-squared & 0.4503 & & & \\
Prob. (F-Stat) & 0.000121 & & & \\
\hline
\end{tabular}

The estimation results (Table 4) show that corporate governance quality variables (CGQ), and the four control variables (SIZE, LEV, RVOL, and GROWTH) simultaneously influence ILLIQ variables (seen from Probabilistic F-stat for models that are 0.000121 , less of critical values of $1 \%, 5 \%$ and $10 \%$ ). In addition to conducting the F-test, the results of the ttest show that corporate governance variables in the ILLIQ model is significant and has coefficient of -0.0000193 with probability values $(0,0003)$ smaller than critical values $(1 \%, 5 \%$ and $10 \%)$. These results indicate that corporate governance has a negative and significant effect on ILLIQ liquidity in the banking subsector. Negative influences indicate that corporate governance has an opposite relationship with Amihud's liquidity where the higher the value of corporate governance, the lower the Amihud liquidity value or in other words, the more liquid. The ILLIQ model has an R-squared value of $45.03 \%$ which means that corporate governance, size, lev, growth, and rvol variables can explain stock liquidity by $45.03 \%$, and the remaining $54.97 \%$ is explained by other factors outside the model.

Table 5 - Regression results of the STO sub-sector banking panel data model

\begin{tabular}{lllll}
\hline Variable & Coefficient & Std. Error & t-Statistic & Prob. \\
\hline CGQ & 0.009897 & 0.004367 & 2.266073 & 0.0256 \\
Size & 0.049618 & 0.016019 & 3.097480 & 0.0025 \\
Lev & 0.287811 & 0.150638 & 1.910616 & 0.0589 \\
Growth & -0.002969 & 0.006268 & -0.473649 & 0.6368 \\
Rvol & 0.661823 & 0.474890 & 1.393636 & 0.1665 \\
Constant & -1.727850 & 0.512608 & -3.370702 & 0.0011 \\
\hline R-squared & 0.9344 & & & \\
Prob. (F-Stat) & 0.000000 & & & \\
\hline
\end{tabular}

The estimation results (Table 5 ) show that corporate governance variables (CG), and the four control variables (SIZE, LEV, RVOL, and GROWTH) simultaneously influence STO variables (seen from Probabilistic F-stat for models that are 0.0000 , less of critical values of $1 \%, 5 \%$ and $10 \%$ ). In addition to conducting the F-test, the results of the t-test show that corporate governance variables in the STO model have is significant and has coefficient of 0.009897 with probability values (0.0256) smaller than critical values $(5 \%$ and $10 \%)$. These results indicate that corporate governance has a positive and significant effect on STO liquidity in the banking subsector. Positive influence shows that corporate governance has a relationship with STO liquidity where the higher the value of corporate governance, the higher the liquidity value of STO or in other words the more liquid. The ILLIQ model has an R-squared value of 0.9344 which means that corporate governance, size, lev, growth, and rvol variables can explain stock liquidity by $93.44 \%$, and the remaining $6.56 \%$ is explained by other factors outside the model. 
Testing the effect of corporate governance on stock liquidity in the ILLIQ and STO models has results that are consistent with the hypothesis of corporate governance that has a positive effect on stock liquidity. The influence of corporate governance on stock liquidity in the ILLIQ model shows that companies that have good governance will have stocks that do not have high price volatility despite large-scale trade in the market. This is because the depth dimension illustrates the market's ability to absorb large-scale trade without having a large influence on stock prices. This shows that the quality of poor governance results in investors being reluctant to buy shares because the company's shares are alleged to have high volatility.

The influence of corporate governance on stock liquidity in the STO model shows that companies that have good governance will tend to have high trading activities each year. This shows that good governance results in the ease of buying and selling shares in the stock market because the shares are attractive to capital market investors. This research has similar results with previous studies, namely there is a positive relationship between corporate governance and stock liquidity.

This research was conducted by assessing the implementation of corporate governance from three aspects, namely the board of commissioners, the board of directors, and the GMS and then seeing the influence of the three simultaneously on stock liquidity. To show deeper results, testing was carried out on each category of indicators, which are the category of board of commissioners, board of directors, and GMS on stock liquidity to see which governance aspects had the most influence on stock liquidity. The test is done by separately regaining each category of indicators on liquidity by controlling the factors of size, leverage, growth, and return volatility.

Table 6 - Regression results of estimating the effect of each indicator category on liquidity

\begin{tabular}{lll}
\hline & ILLIQ & STO \\
\hline Board of Commisioners & $-0.0000124^{* * *}$ & $0.022777^{\star * *}$ \\
Board of Director & -0.0000117 & 0.006558 \\
GMS & Near singular matrix & Near singular matrix \\
\hline
\end{tabular}

Superscripts ${ }^{* * *},{ }^{* * *}$ indicate statistical significance at $10 \%, 5 \%, 1 \%$.

Table 6 shows that from the overall indicator category, the board of commissioners' category has a significant influence on both ILLIQ and STO liquidity, while the board of directors' category and GMS' category do not have a significant influence. This result is in line with the function of the board of commissioners as a supervisor whose duty is to provide input and direction to the board of directors in realizing the company's annual work plan and the company's long-term plan with performance results that will be accountable to investors at the GMS. In this case the board of commissioners has a crucial role. This result is consistent with the fact that corporate governance in Indonesia is focused on aspects of the board of commissioners (World Bank 2010).

\section{MANAGERIAL IMPLICATIONS}

The quality of corporate governance reflects the level of relationship of three important factors in the company, namely the board of commissioners (as the owner's representative), the directors (as agents), and shareholders (as owners). To realize good corporate governance, in order to choose an independent board of commissioners, it is absolutely necessary to have competencies in accordance with their fields. Suppose that for the competence of the audit field, it must be filled by someone who has a background or experience in the field of audit, for the competency of the risk monitoring field, it must be filled by someone who has a background or experience in the field of risk management. The company's performance can only be achieved well if corporate governance has been running in accordance with the regulations set by the banking regulator, which is the government through $\mathrm{BI}$ and $\mathrm{OJK}$. The low quality of corporate governance is something that is not good in the eyes of investors because the company's stock price can fluctuate at any time and this 
makes the company's shares are not much in demand so it will be difficult to sell at any time. This shows the quality of good corporate governance is crucial in the eyes of investors because it pictures of how safe the company is used as a place to invest.

\section{CONCLUSION}

The results of the study show that the banking sub-sector in Indonesia has implemented good corporate governance practices established by the OJK. This can be seen in the annual report issued by the company which is reflected in the indicator values in this thesis. The relationship between the board of commissioners, directors and shareholders has been running well. The composition of the board of commissioners has complied with the rules, namely $50 \%$ is a commissioner or an independent party and has competencies in accordance with their fields so that the supervision function of banking operations runs optimally. A good corporate governance will increase investors' trust so the companies' stocks will be liquid. It can be seen from the test results that corporate governance has a significant negative effect on ILLIQ liquidity and is significantly positive for STO liquidity of the three corporate governance components. The components of the board of commissioners have a significant influence on stock liquidity, it can be seen from the results of the tests that the board of commissioners' indicators has a significant negative effect on ILLIQ liquidity and are significantly positive for STO liquidity.

\section{REFERENCES}

1. Ajina A, Lakhal F, Sougne D. 2015. Institutional investors, information asymmetry, and stock market liquidity in France. IJMF. 11 (1):44-59.

2. Ali S, Liu B, Su JJ. 2017. Corporate governance and stock liquidity dimensions: Panel evidence from pure order-driven Australian market. International Review of Economics\&Finance. 50:275-304.

3. Amihud Y. 2002. Illiquidity and stock returns: cross section and time-series effects. Journal of Financial Markets. 5 (1): 31-56.

4. Bacidore J M, Sofianos G. 2002. Liquidity provision and specialist trading in NYSE-listed non-U.S. asymmetry and stock liquidity. Journal of Financial Economics. 63: 133-158.

5. Brockman P, Chung DY. 2003. Investor protection and firm liquidity. Journal of Finance. 58: 921-937.

6. Butler AW, Grullon G, Weston JP. 2005. Stock market liquidity and the cost of issuing equity. JFQA. 40 (2): 331-348.

7. Chung KH, Elder J, Kim JC. 2010. Corporate governance and liquidity. JFQA. 45 (2): 265-291.

8. Cheung WM, Chung R, Fung S. 2015. The effects of stock liquidity on firm value and corporate governance: Endogeneity and the REIT experiment. Journal of Corporate Finance. 35: 211-231.

9. Studies, 20, 1359-1388.

10. Diamond DW. 1985. Optimal release of information by firms. Journal of Finance. 40 (4):1071-1091.

11. Diamond DW, Verrechia RE. 1991. Disclosure, liquidity, and the cost of capital. The Journal of Finance. 46 (4):1325-1259.

12. Foo YB, Zain MM. 2010. Board indepence, board diligence and liquidity in Malaysia: $A$ research note. Jornal of Contemporary Accounting\&Economics. 6 (2): 92-100.

13. Glosten LR, Milgrom PR. 1985. Bid, ask and transaction prices in a specialist market with heterogeneously informed traders. Journal of financial Economics. 14 (1): 71-100.

14. Handa P, Schwartz RA. 1996. How best to supply liquidity to a securities market. The Journal of Portfolio Management. 22 (2):44-51.

15. Harris L. 2003. Trading and Exchange: Market Microstructure for Practioners. New York (US): Oxford University Press. 
16. Ho T, Stoll HR. 1981. Optimal dealer pricing under transactions and return uncertainty. Journal of financial Economics. 9 (1): 47-73.

17. [IDX] Indonesia Stock Exchange. 2016. IDX Statistics Annually 2016. Jakarta (ID): IDX.

18. Jensen MC, Meckling WH. 1976. Theory of the firm: Managerial behavior, agency costs and ownership structure. Journal of financial Economics. 3 (4): 305-360.

19. Kuper A. 2005. The Social Science Encyclopedia. Edisi ke-3. Kuper A, Kuper J, editor. London (UK): Routledge.

20. Leuz C, Nanda D, Wysocki P. 2003. Earnings management and investor protection: An international comparison. Journal of Financial Economics. 58:3-27.

21. McKinsey\&Co. 2002. Global Investor Opinion Survey on Corporate Governance: Key Findings.

22. Merton RC. 1987. A simple model of capital market equilibrium with incomplete information. The Journal of Finance. 42 (3): 483-510.

23. Nam SW, Nam IC. 2004. Corporate governance in Asia: Recent Evidence from Indonesia, Republic of Korea, Malaysia and Thailand. Tokyo (JP): Asian Development Bank Institute.

24. [OJK] Otoritas Jasa Keuangan. 2015. Peraturan Otoritas Jasa Keuangan Nomor 21/POJK.04/2015 Pedoman Penerapan Tata Kelola Perusahaan Terbuka di Indonesia. Jakarta (ID): OJK.

25. [OJK] Otoritas Jasa Keuangan. 2015. Peraturan Otoritas Jasa Keuangan Nomor 32/POJK.04/2015 Rencana dan Penyelenggaraan Rapat Umum Pemegang Saham. Jakarta (ID): OJK.

26. [OJK] Otoritas Jasa Keuangan. 2015. Peraturan Otoritas Jasa Keuangan Nomor 33/POJK.04/2015 Direksi dan Dewan Komisaris Emiten atau Perusahaan Publik. Jakarta (ID): OJK.

27. [OJK] Otoritas Jasa Keuangan. 2015. Peraturan Otoritas Jasa Keuangan Nomor 34/POJK.04/2015 Komite Nominasi dan Remunerasi Emiten atau Perusahaan Publik. Jakarta (ID): OJK.

28. [OJK] Otoritas Jasa Keuangan. 2015. Peraturan Otoritas Jasa Keuangan Nomor 55/POJK.04/2015 Pembentukan dan Pedoman Pelaksanaan Kerja Komite Audit. Jakarta (ID): OJK.

29. [OJK] Otoritas Jasa Keuangan. 2015. Surat Edaran Otoritas Jasa Keuangan Nomor 32/POJK.04/2015 Rekomendasi Penerapan Pedoman Tata Kelola Perusahaan di Indonesia. Jakarta (ID): OJK.

30. [OJK] Otoritas Jasa Keuangan. 2016. Peraturan Otoritas Jasa Keuangan Nomor 55/POJK.03/2016 Penerapan Tata Kelola bagi Bank Umum di Indonesia. Jakarta (ID): OJK.

31. [OJK] Otoritas Jasa Keuangan. 2017. Statistik Mingguan Pasar Modal Desember 27-29. Jakarta (ID): OJK.

32. Prommin $P$, Jumreornvong $S$, Jiraporn P. 2014. The effect of corporate governance on stock liquidity: The case of Thailand. International Review of Economics\&Finance. 32:132-142.

33. Sawicki J. 2009. Corporate governance and dividend policy in Southeast Asia pre- and post-crisis. The European Journal of Finance. 15 (2):211-230.

34. Switzer LN, Wang J. 2013. Default risk estimation, bank credit risk, and corporate governance. Financial Markets, Institutions\&Instruments. 22 (2): 91-112.

35. [WB] World Bank. 2010. Report on the Observance of Standards and Codes: Corporate Governance Country Assessment Indonesia. 